\title{
車載情報系光 LAN
}

\author{
柴田 宣* \\ Fiber-Optic LAN Systems in Automobile Applications
}

Nori SHIBATA*

$*$ 矢崎総業株式会社技術研究所（

*YAZAKI Research and Technology Center, YAZAKI Corporation (1500 Mishuku, Susono-shi, Shizuoka 410-1194)

\section{1. はじめに}

「安全・安心」，「環境」，「快適性」といった自動車市場 のニーズに応え, 車の高性能化, インテリジェント化, 軽 量化へ向けて車の電子化が急速に進展している。「安全・ 安心」は「衝突防止・走行支援」などを実現する上でセン サ機能の高度化と電子化による細かな制御性が求められる。 「環境」は「燃費の向上」を目指して, 車の軽量化やエン ジ点火のタイミングの最適化による $\mathrm{CO}_{2}$ 削減や化石燃料 の効率的活用に貢献することを意図する。また，「快適性」 は, 広い車内空間を確保するにあたり，車の電子化普及に よる電子制御ユニット (ECU: Electronic Control Unit)の増大 やECU間のリンクを構成するワイヤーハーネス(Wiring Harness)に対する省スペース化を促す。ECUの数は今後も増大 する傾向にあり, 制御対象は多様化し, ECUの回路は複雑 さを増す。また，ECU間の配線数も増大し，ECU間を結ぶ ワイヤーハーネスは量的に増大するとともに, 多品種化す る。ECU間のリンクの増大は当然の㷌着として, 車載ネッ トワークがハンドリングする情報量の増大を意味する。し たがって, 車載ネットワークの高速・大容量化が求められ, 新たなアプリケーションを実現するためのネットワーク高 度化が志向される。

車載に搭載される LAN システムは,「車体系」,「走行制 御系」,「情報系」の大きく 3 つに分類される。「車体系」は パワーウインドウ, ワイパー, フロント/リアランプ, 空調 などが対象である。「走行制御系」は「走る, 曲がる, 止 まる」の基本性能を掌り, 車両の安全運行上きわめて重要 なエンジン, ブレーキ, サスペンションなどが対象となる。 ブレーキペダルを踏んでも効かない状況を想像すればわか るように，「走行制御系」は高い信頼性と実時間応答性が 要求される。「情報系」はナビゲーション, ワイヤレス チューナ, ディスプレイなどのマルチメディア端末を対象 とするLAN システムであり, 端末機器の追加などに対する 拡張性が要求される。
昨今話題の車載LANに「走行制御系」のFlexRay，「情 報系」の MOST (Media Oriented Systems Transport)や IDB1394 (ITS Data Bus 1394)がある。FlexRayは車体軽量化の 流れから，機械的制御システム（例えば，ステアリングコ ラム, ステアリングギア, 油圧ホース, オイルポンプから なるパワーステアリング）をワイヤーによる電気信号で制 御する方式に置き換えるX-by-wire（例えば，X=Steer， Brake, Suspension）を実現する技術として登場した。現在, 「車体系」,「走行制御系」の制御用ネットワークとして広 く普及しているCAN (Controller Area Network) は最大 $1 \mathrm{Mb} / \mathrm{s}$ の伝送速度であるが, FlexRay は最大 $10 \mathrm{Mb} / \mathrm{s}$ を提供し，高 速性とネットワークの 2 重化による信頼性向上を特徴とす る。「情報系」は1994年にメルセデスベンツやジャガーに 採用された AV (Audio Visual)系のインタフェース規格であ る D2B (Digital Domestic Data Bus)からMOSTへと移行し, IEEE-1394の 1394b 規格を基本とする新しい車載規格であ るIDB-1394 仕様が登場した。「市場のニーズ」と「車への デマンド」の観点から整理した走行制御系LAN および情報 系LANのトレンドを図 1 に示す。また,「安全・安心」, 「環境」,「快適性」の観点から整理した「車の電子化」の 具体的対象のいくつかを図 2 に示す。

本稿では, まず, 「車の光化」の位置づけについて述べ, MOST やIDB-1394 に代表される情報系光 LANに使用され るプラスチックファイバ(POF: Plastic Optical Fiber) および 光トランシーバ(FOT: Fiber-Optic Transceiver)の諸元を示 す。さらに, 車に搭載される光伝送媒体が短尺であること から, $10 \mathrm{~m} \sim 100 \mathrm{~m}$ 程度の短尺試料でも伝送帯域および光 損失の評価が可能な測定法を紹介する。

\section{2. ワイヤーハーネスと車の光化}

車載システムを構成する機器はワイヤーハーネスと呼ば れる自動車用組電線により接続される。図 3 は車載におけ るワイヤーハーネス配置の様子とワイヤーハーネスの外観 写真を示す。車 1 台当たりのワイヤーハーネスの総延長は 


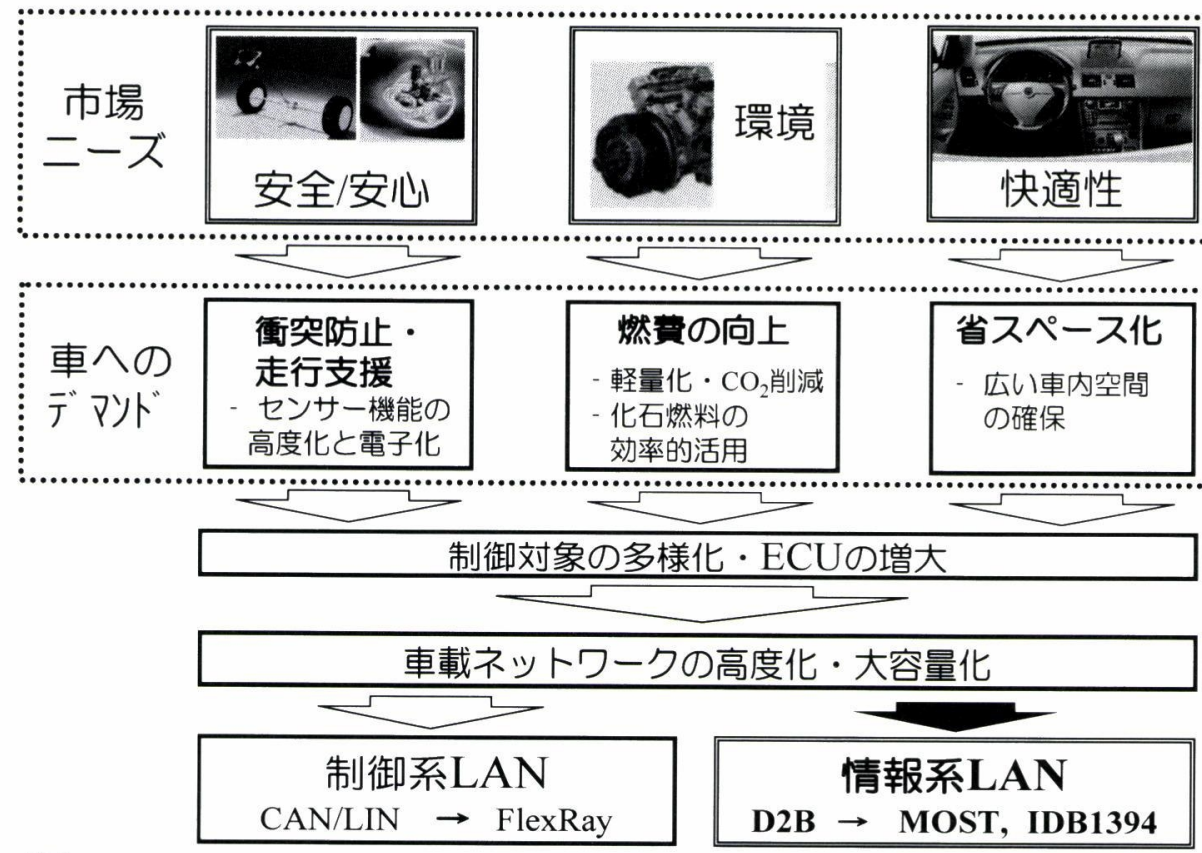

注）LIN (Local Interconnect Network)はCANのサブネットワーク

図1.市場ニーズと車へのデマンド，および走行制御系／情報系LAN の新たな展開

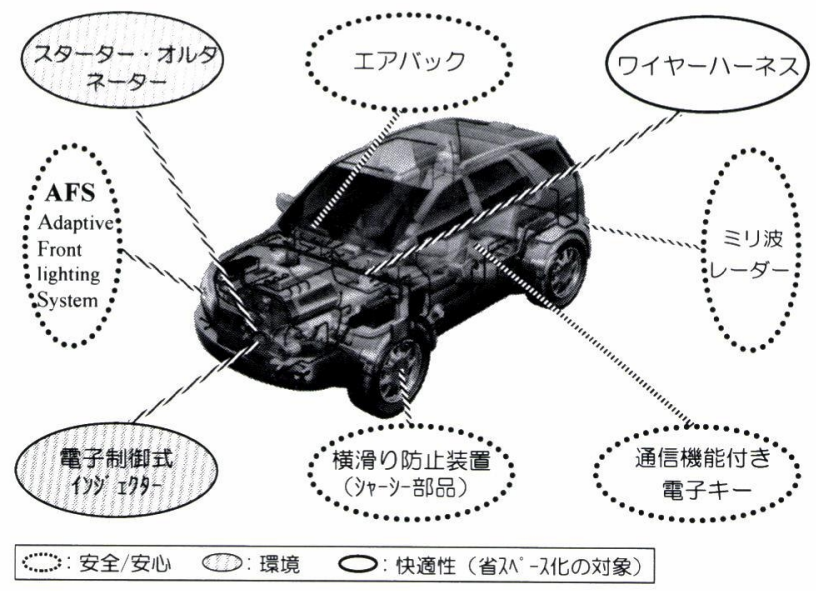

図 2. 安全·安心, 環境, 快適性の対象となる車載エレメント

約 3,000 m/台であり, 車体総重量に占めるワイヤーハーネ スの重量は 5 ～ $10 \%$ といわれる。

車の電子化の潮流は, 車載情報端末の増加之機器間の連 携が底流にある。この底流がもたらすものに，機器および ワイヤーハーネスの数量増加と車体における空間占有率の 増加がある。したがって, 省スペース化や軽量化を実現す るためには，媒体や信号終端部におけるインタフェースの 共用が必要となる。先に述べたとおり, 情報系LAN は情報 端末の追加に対し, 拡張性が要求される。メタル線では通 常, この端末機器追加に対して別線を必要とするため, 省 スペース化, 軽量化への寄与が難しい。一方, POFなよ゙の 光ファイバは高速・大容量化への対応が容易であり, 多数 の端末からの信号を同一ファイバ中に多重化することがで きるため, 別線を必要としない。多重化は高速化を意味す

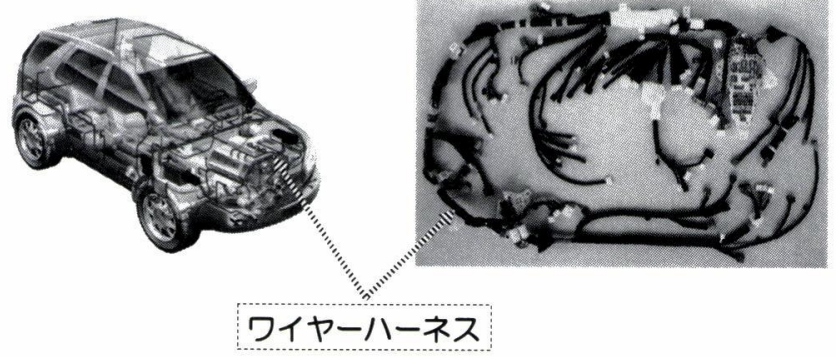

図3. ワイヤーハーネス配置の様子と外観

る時分割多重 TDM (Time-Division-Multiplexing) や大容量化 のための波長多重 WDM (Wavelength-Division-Multiplexing) により実現することができる。したがって，光ファイバの 両端に信号の多重・分離機能を有する終端回路を含むFOT モジュールを用いて，省スペース化や軽量化に寄与できる。 ただし, メタル線と比較して, 低コスト化と既存のワイ ヤーハーネスと同等の取り扱い（例えば，車載環境や車両 組み付け作業）ができることが光化を実現する鍵となる。 図 4 は, 以上述べた「車の電子化」をトリガーに, 省ス ペース化と軽量化を実現する「車の光化」への流れを示す。 「車の光化」は「省スペース化」と「軽量化」を実現す る1つのソリューションを提供する。ただし, 光ならでは のアプリケーションやコンテンツが車載提供サービスとし て普及することが，車光化の本流であろう。FTTH (FiberTo-The-Home) サービス ${ }^{1)}$ として登場するトリプルプレイ（高 速インターネットアクセス, 音声, 映像配信の 3 つのサー ビス）の例などは, 車光化のヒントを与える。光化の鍵と なるキラーアプリケーションとして動画が考えられる。例 


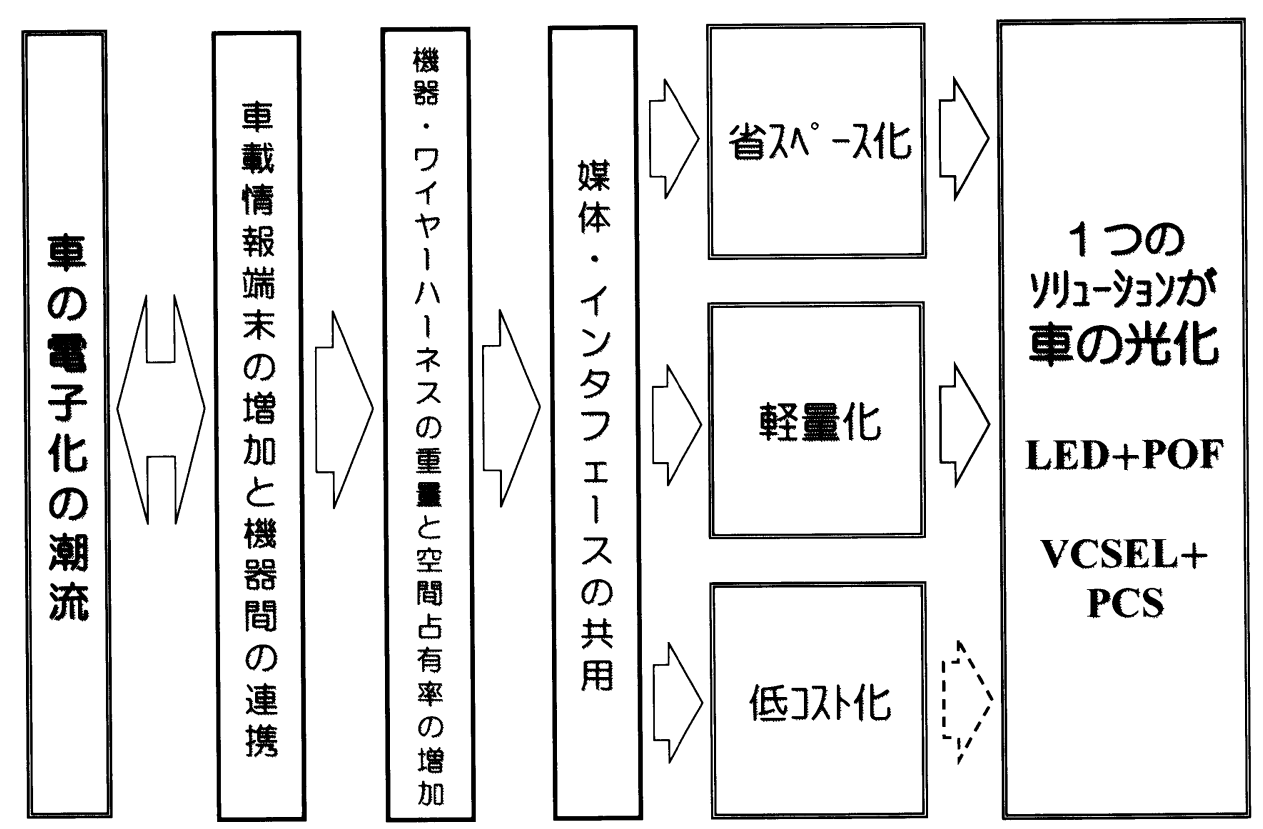

図4. 車の電子化の潮流から車の光化への流れ

えば，安全性の精度向上を狙いとして, FlexRay 導入が期 待される分野に実時間性が要求される車載カメラシステム がある。複数のカメラを連携させ, 実時間性を要求する動 画転送処理などは光ならではのネットワーク導入を推進す る鍵となろう。情報系光 LAN の MOST や IDB-1394 が規定 する光伝送媒体はPOFである。また, 光源にはLEDが用 いられる。 $25 \mathrm{Mb} / \mathrm{s}$ の伝送速度を提供するMOST 規格に MOST@25がある。これはLED とPOFにより光LANを構 成することができる。さらなる高速・大容量化を意識した $150 \mathrm{Mb} / \mathrm{s}$ の MOST@150や200 Mb/s あるいは $400 \mathrm{Mb} / \mathrm{s}$ の IDB1394 規格では VCSEL (Vertical Cavity Surface Emitting Laser) ${ }^{2)}$ と PCS (Polymer Clad Silica-core) ファイバの組み合わ せによる光LANが期待されている。

\section{MOST とIDB1394}

情報系LAN の標準化のスタートは1995年のアメリカに おけるIDB (ITS Data Bus)委員会の IDB-T (Telematics)通信 規格策定である。1999年には IDB-T の普及活動および IDBM (Multimedia)の技術検討を目的にIDBフォーラムが設立 された。一方，欧州では1998年にドイツ自動車メーカが中 心となって MOST Cooperationを設立した。MOSTは 2001 年にBMW 7 Seriesに採用され，01年 06年の実績は 38 車 種（+6車種）に採用され，欧州を中心に市場を拡大して いる。国内は1998年にITS 普及を支える車載標準高速デー タバスの検討を目的にIDBタスクフォースが自走協／自工 会により設立された。デジタル $\mathrm{AV}$ 機器とコンピュータを 接続するためのインタフェース規格である IEEE-1394 の仕 様を車載向けに最適化したものがIDB-1394である。2000年 にIDB フォーラムが IEEE-1394 の標準化団体である 1394TA
(Trade Association) と合同で, IEEE-1394 の車載化を検討す る 1394AuWG (1394 Automotive Working Group)を設立し, IDB-1394 規格が検討されるようになった。

図 5 は車体系, 走行制御系, 情報系を対象に整理した CAN, FlexRay, MOST, IDB-1394 の伝送速度と伝送媒体を示 す。ここで二重枠は車載実績があるシステムを示す。車載 実績のある情報系光 LAN として, $5.6 \mathrm{Mb} / \mathrm{s}$ の D2B と 25 $\mathrm{Mb} / \mathrm{s}$ のMOST@25 がある。また, メタルを使用する MOST @ 25 と $100 \mathrm{Mb} / \mathrm{s}$ のIDB-1394 の規格が存在する。MOST で最 高速の規格は $150 \mathrm{Mb} / \mathrm{s}$ の MOST@150であり, IDB-1394 規 格には $100,200,400 \mathrm{Mb} / \mathrm{s}$ の 3 つの伝送速度がある。表 1 に D2B, MOST@25, IDB-1394の網トポロジー, 伝送路符号, クロックレート, データレート, 伝送媒体, およびFOT と 光コネクタの外観を示す。D2B と MOST はリング網, IDB1394 はツリーバス型の網トポロジーを採用している。 伝送路符号はすへてての方式共通に，符号“0”または“1” が連続する場合，同じ振幅レベルを維持し続ける NRZ (Non-Return-to-Zero) フォーマットが用いられる。クロック レートとデータレートの比から伝送効率を比較すると, IDB-1394 が 80\%と最も高く, D2Bは 47\%, MOST@ 25 は $45 \%$ である。伝送媒体は屈折率分布が階段状 (Step-Index) のSI-POF が用いられる。

図6にPOF 心線の構造を示す。導波路構造はポリメタク リル酸メチル $(\mathrm{PMMA})$ からなるコアとフッ素系樹脂からな るクラッドにより構成され，コア径/クラッド径は $980 \mu \mathrm{m} /$ $1,000 \mu \mathrm{m}$ である。心線構造は $1.5 \mathrm{~mm}$ 径の 1 次被覆と $2.3 \mathrm{~mm}$ 径の 2 次被覆から構成され，2次被覆材の強化により保護 部材なしでワイヤーハーネスへの組み込みを可能としてい る。MOST とIDB-1394に使用されるPOFおよびFOT の仕 


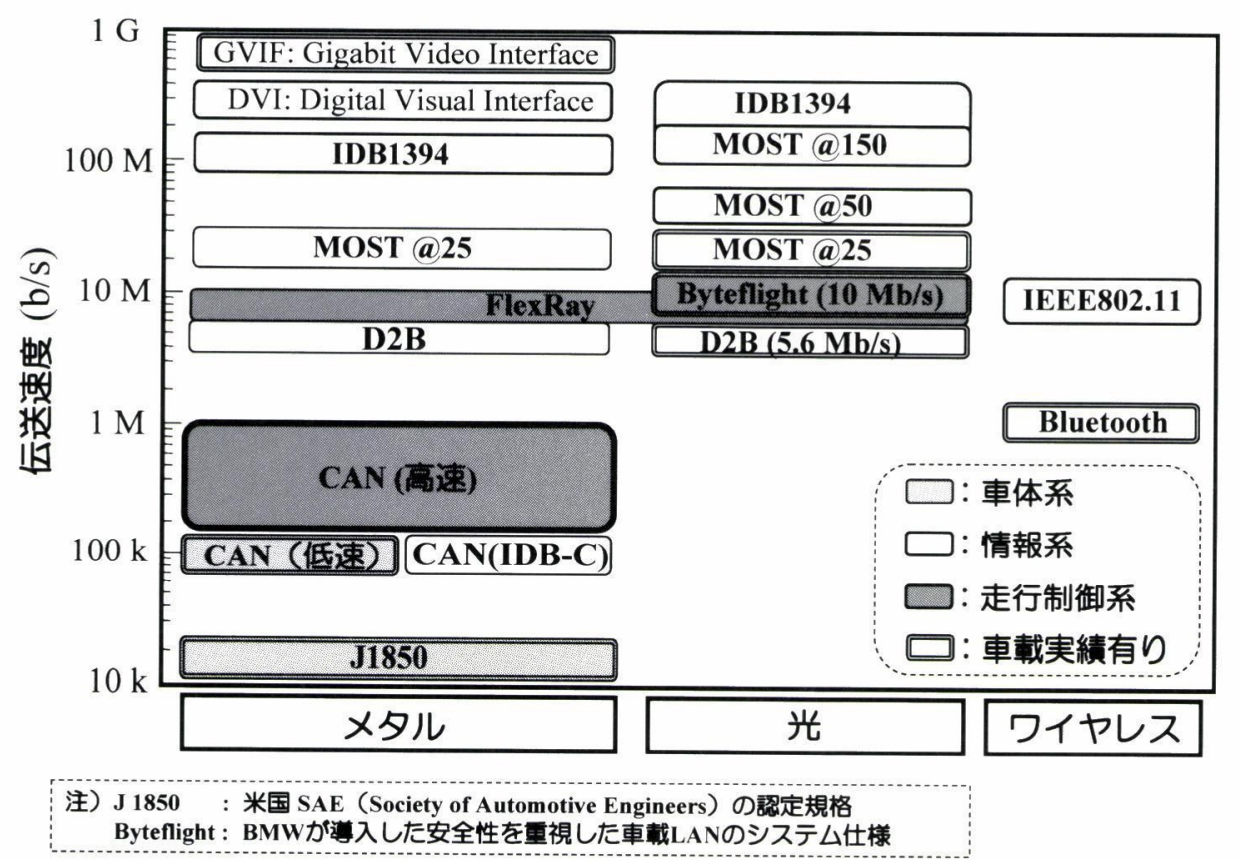

図 5. 車載 LAN システムの伝送速度と伝送媒体

表 1.D2B, MOST@25, IDB-1394 の概要

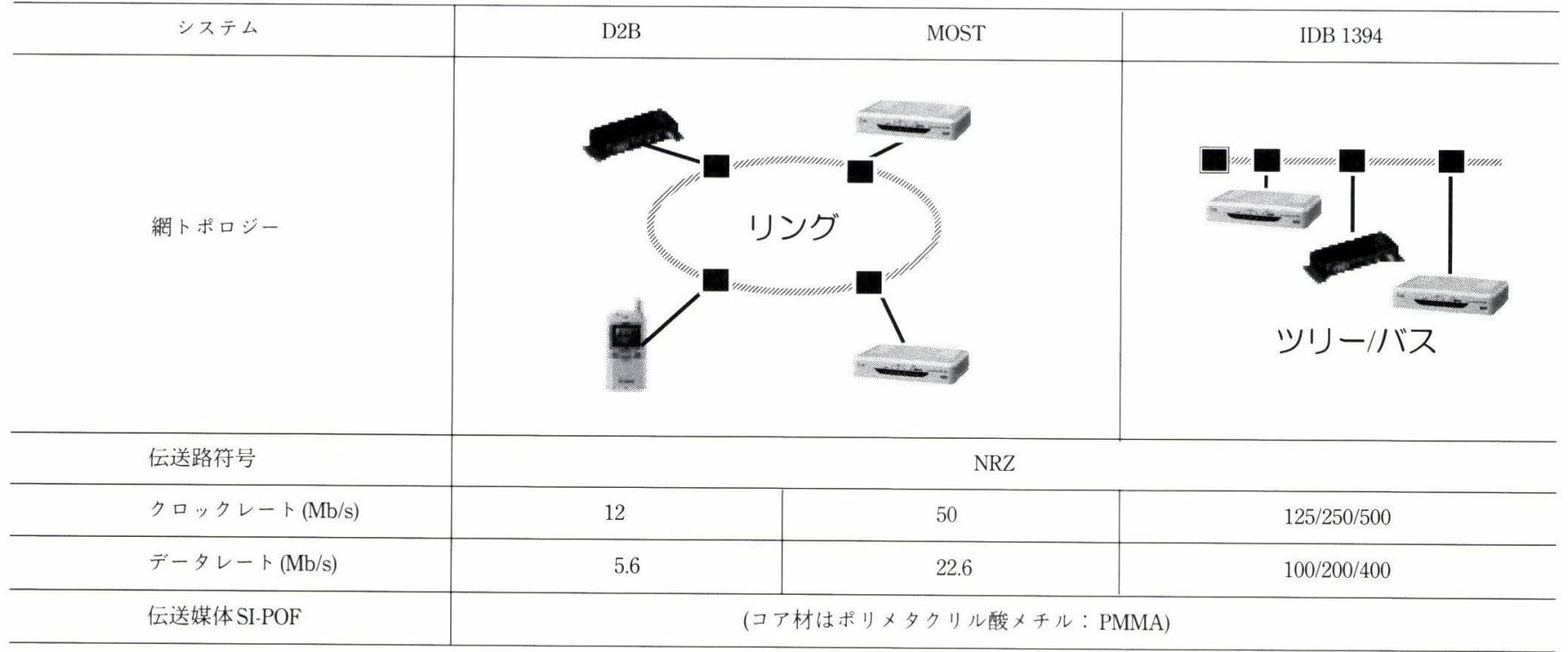

様をそれぞれ表 2 と表 3 に整理した。POF は温度範囲, 伝 送帯域, 光損失, 開口数 NA (Numerical Aperture), 最小曲 げ半径が規定される。また, FOT は温度範囲, 動作波長, 出力光電力, 受光感度が規定される。FOTの動作波長は $\mathrm{POF}$ の低損失波長域である $650 \pm 30 \mathrm{~nm}$ で規定されている。 表からわかるように，ハーネス用POF とFOT の温度範井 は通常 $-40 \sim 85^{\circ} \mathrm{C}$ であるが，ピグテイル用POF については 機器内での使用やはんだ付けの高温対応として, -40 $105^{\circ} \mathrm{C}$ が規定されている。

\section{4. 短尺光ファイバの伝送特性評価技術}

先に述べたMOST@150や200, 400 Mb/s の IDB-1394 で期
待される光源と媒体の組み合わせにVCSEL とPCS ファイバ がある。表 4 にPOF とPCS ファイバの光伝送特性および適 用温度範囲の比較を示す。PCS ファイバはPOFに比へ, 広 帯域性と低損失性を有していることがわかる。表 4 で伝送 帯域の值を例にとると，200 MHz/10m あるいは $1 \mathrm{GHz} / 20 \mathrm{~m}$ である。これらの数值から短尺の光ファイバでの伝送帯域 評価が重要であることがわかる。ここでは, POFや PCS ファイバの伝送特性を把握する上で重要な伝送帯域と光損 失について，短尺ファイバでも光伝送特性の評価が可能な 測定法を紹介する。

4.1 シャトルパルス法

短尺の光ファイバを用いて伝送帯域を評価する方法に 


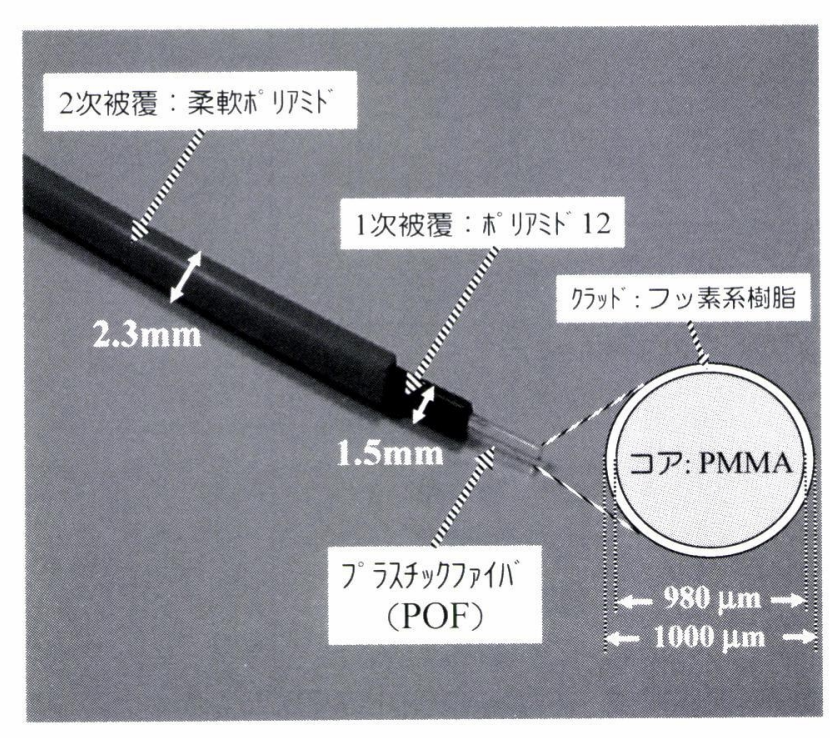

図6. POF心線の構造

表 2. MOST のPOF およびFOT の仕様

\begin{tabular}{l|c|c|c}
\hline \multicolumn{1}{c|}{ 項 目 } & ハーネス用 POF & ピグテイル用 POF & FOT \\
\hline 温度範用 $\left({ }^{\circ} \mathrm{C}\right)$ & $-40 \sim+85$ & $-40 \sim+105$ & $-40 \sim+85$ \\
\hline 伝送帯域 $(\mathrm{MHz} / 10 \mathrm{~m})$ & \multicolumn{2}{|c|}{200} & - \\
\hline 光損失 $(\mathrm{dB} / \mathrm{m}) @ 650 \mathrm{~nm}$ & \multicolumn{2}{|c|}{0.2} & - \\
\hline 開口数 $\mathrm{NA}$ & $0.5 / 0.6$ & 0.6 & - \\
\hline 最小曲げ半径 $(\mathrm{mm})$ & \multicolumn{2}{|c|}{25} & $650 \pm 30$ \\
\hline 動作波長 $(\mathrm{nm})$ & - & - & $-10 \pm-2$ \\
\hline 出力光電力 $(\mathrm{dBm})$ & - & - & $-24 \pm-2$ \\
\hline 受光感度 $(\mathrm{dBm})$ & - & - & \\
\hline
\end{tabular}

【注】ピグテイル用は, (1)機器内に収容, (2)はんだ付けのため高温対応の仕 様
シャトルパルス法 ${ }^{3), 4)}$ (光パルス周回法とも呼ばれる）があ る。図7にシャトルパルス法を用いた伝送帯域測定系を示 す5)。POFやPCS ファイバのサンプル長は $10 \mathrm{~m} \sim 100 \mathrm{~m}$ 程度 である。波長が $647 \mathrm{~nm}$ の極短パルス光源 $\mathrm{LD}$ からの光パル

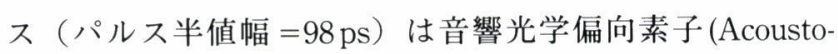
Optic Deflector, 以下AO素子と呼ぶ)をして被測定ファイ バに入射される。被測定ファイバを伝搬し, ファイバ出射 端から出射した光パルスは再度 $\mathrm{AO}$ 素子を通過する。その 際, $\mathrm{AO}$ 素子が “on”の状態では, 光パルスは $\mathrm{AO}$ 素子の 1

表 3. IDB-1394のPOF およびFOT の仕様

\begin{tabular}{l|c|c}
\hline \multicolumn{1}{c|}{ 項 目 } & SI-POF & FOT \\
\hline 温度範囲 $\left({ }^{\circ} \mathrm{C}\right)$ & $-40 \sim+85$ & $-40 \sim+85$ \\
\hline 伝送帯域 $(\mathrm{MHz} / 10 \mathrm{~m})$ & 200 & - \\
\hline 光損失 $(\mathrm{dB} / \mathrm{m}) @ 650 \mathrm{~nm}$ & 0.25 & - \\
\hline 開口数 $\mathrm{NA}$ & $0.6 \pm 0.05$ & - \\
\hline 最小曲げ半径 $(\mathrm{mm})$ & 15 & $650 \pm 30$ \\
\hline 動作波長 $(\mathrm{nm})$ & - & $-7.5 \sim-2$ \\
\hline 出力光電力 $(\mathrm{dBm}) @ 25^{\circ} \mathrm{C}$ & - & $-22 \sim-2$ \\
\hline 受光感度 $(\mathrm{dBm})$ & - & \\
\hline
\end{tabular}

表 4. POF とPCS ファイバの光伝送特性および適用温度 範囲の比較

\begin{tabular}{c|c|c}
\hline \multicolumn{1}{c|}{ 項 } & SI-POF & PCS ファイバ \\
\hline 伝送帯域 & $200 \mathrm{MHz} / 10 \mathrm{~m}$ & $1 \mathrm{GHz} / 20 \mathrm{~m}$ \\
\hline 光損失 $(\mathrm{dB} / \mathrm{m})$ & 0.2 & 0.01 \\
\hline 適用温度範讲 $\left({ }^{\circ} \mathrm{C}\right)$ & $<85$ & $<105$ \\
\hline
\end{tabular}

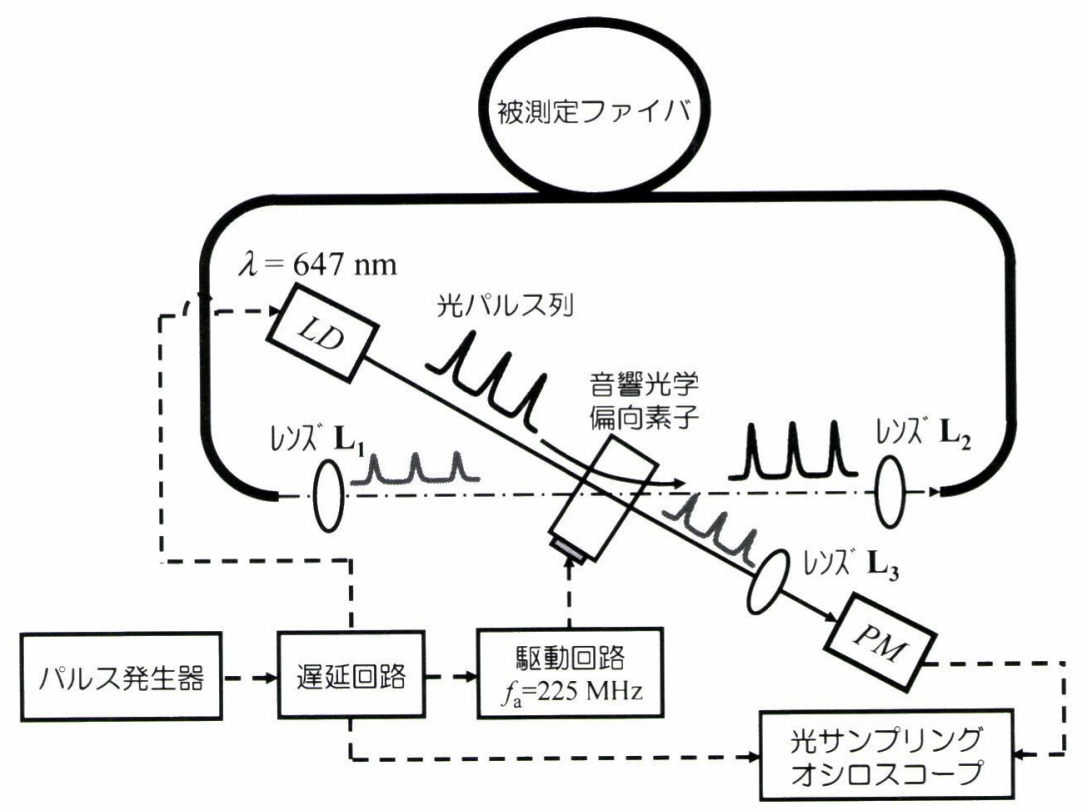

図7.シャトルパルス法を用いた伝送帯域測定系 
次回折光として光検出器 PMへ導かれ, “off” の状態では 0 次回折光として直進し, 被測定ファイバへ再度入射される。 2 周回目以降の光パルスについても, $\mathrm{AO}$ 素子の “on” と “off”を時間的に制御することにより, 被測定ファイバ中 を $n$ 周回 $(n=1,2,3, \ldots)$ した光パルスを PM で検出すること ができる。

図 8 は屈折率分布がほぼ 2 乗分布の GI-PCSファイバにつ いて測定した周回光パルス列と周回光パルス波形を示す。 試料ファイバ長は $l=100 \mathrm{~m}$ である。図 8(a) から, 周回光パ ルス列は 11 周回まで観測され, 光パルスのピーク值を結ぶ 傾向線から 1 周回当たりの測定系の光損失は $3.1 \mathrm{~dB}$ である ことがわかる。測定可能な光パルス周回数は系のダイナ
ミックレンジできまる。LDからの出射光パルスのピーク值 を $0 \mathrm{dBm}(=1 \mathrm{~mW})$ とすると, 光検出器 $\mathrm{PM}$ の最低受光感度 は約 $-40 \mathrm{dBm}$ であるため, 測定系のダイナミックレンジは $40 \mathrm{~dB}$ となる。 $40 \div 3.1 \fallingdotseq 12.9$ より, この場合, 12 周回までの 光パルスが検出可能となる。図 8(b) は励振条件（同軸入射 と軸ずれ入射）のちがいにより得られた周回光パルス波形 を示す。ここで, $n=0$ の光パルスはLDからの出射パルス を意味し, $n=1,4,6$ はそれぞれ 1 周回, 4 周回, 6 周回後の 出射パルスを意味する。同軸入射と比較して, 軸ずれ入射 では光パルスの前縁部に盛り上がりが観測され, 伝送帯域 制限となることが予測される。図 9 は光パルス半值幅と伝 送帯域の距離依存性を示す。図で○と点線で示した曲線は

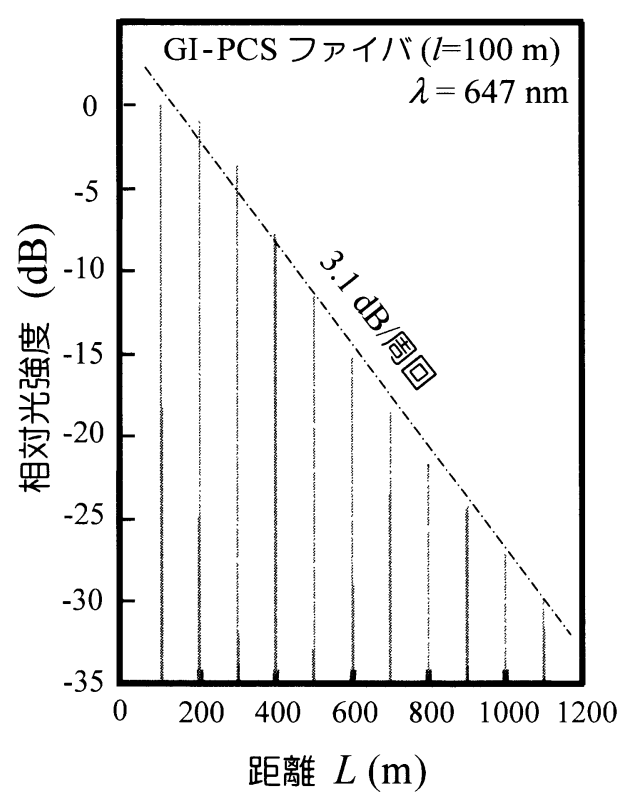

(a)

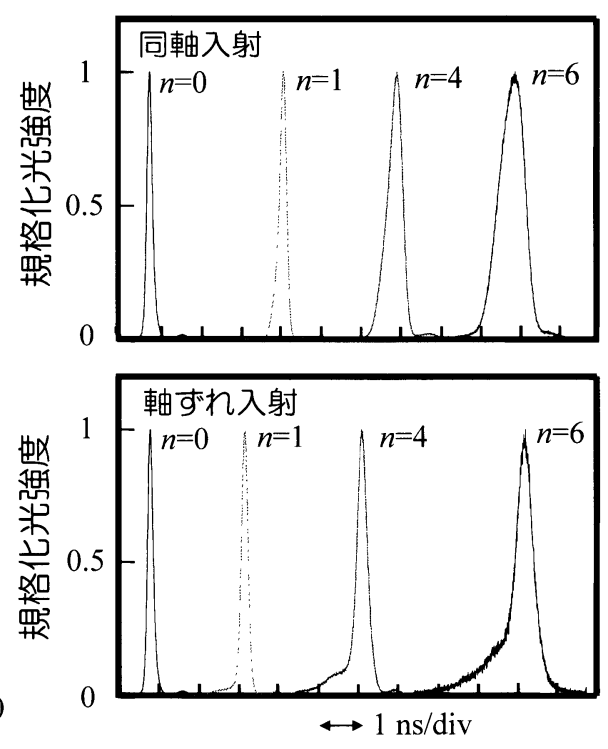

時間 $T(\mathrm{~ns})$

(b)

図 8. (a) 光パルス列と(b) 異なる励振条件で得られた周回光パルス波形

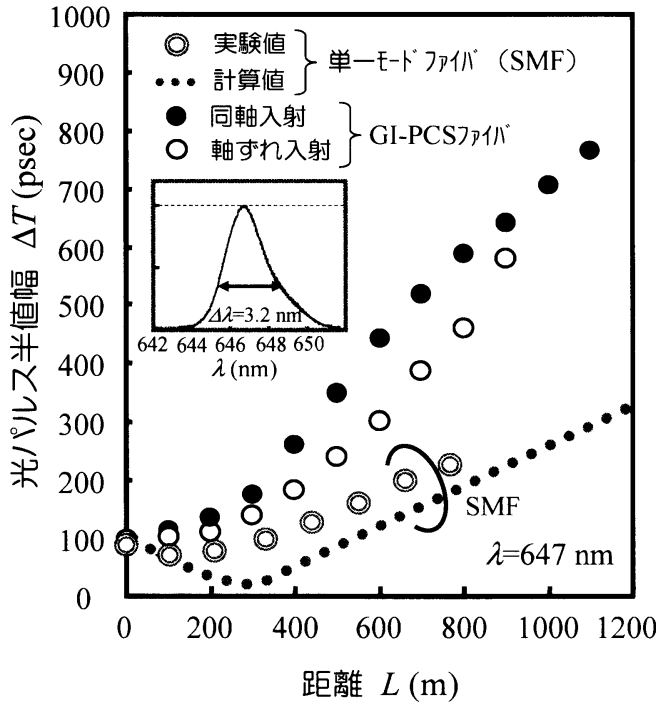

(a)

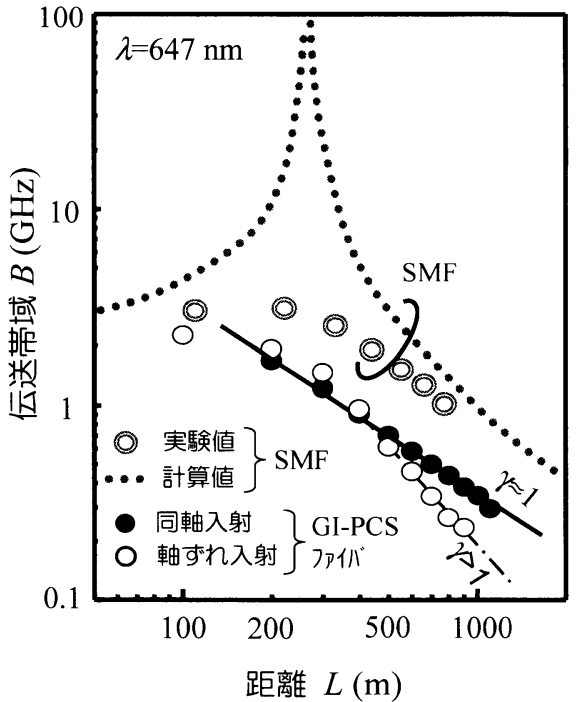

(b)

図9. (a) 光パルス半值幅と (b) 伝送帯域の距離依存性 


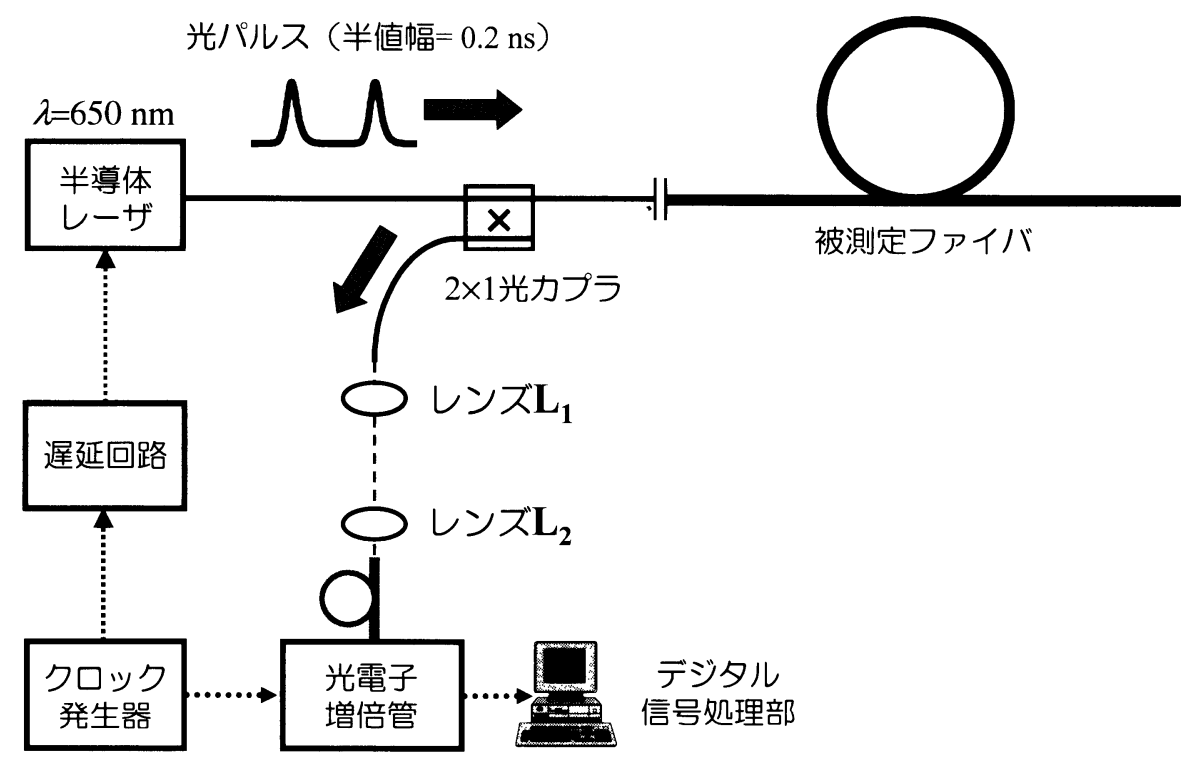

図 10. フォトンカウンティング OTDRによる光損失測定系

単一モードファイバ(SMF)に対する実験値と理論曲線を示 す。図 9(a)で, SMFに対するパルス幅の理論曲線が距離 $L=300 \mathrm{~m}$ 近傍で入射光パルスより狭くなり，伝送帯域が $100 \mathrm{GHz}$ 程度となるのはLD パルスのチャーピングとSMF の 色分散特性に起因する ${ }^{6)}$ 。すなわち， $L<300 \mathrm{~m}$ において， SMF 中で光パルスの前縁部が遅れ, 後縁部が進むため, 光 パルス圧縮が発生する。GI-PCSファイバについて励振条件 のちがいによるパルス半值幅と伝送帯域を比較すると，同 軸入射の方がパルス半值幅は大きく，伝送帯域は 500 $\mathrm{m}<L<800 \mathrm{~m}$ で広くなっていることがわかる。伝送帯域 $B$ の距離依存性は, 帯域の距離に対する傾き $\gamma$ を用いて議論 される。同軸入射では伝送帯域の距離特性が $\gamma \approx 1$ であるの に対し，軸ずれ入射では $L>500 \mathrm{~m}$ において $\gamma>1$ となり，急 激に伝送帯域が狭くなることがわかる。図9(b)から，いず れの励振条件においても $L=100 \mathrm{~m}$ において伝送帯域幅 $B \approx 2$ $\mathrm{GHz}$ である。これより, 被測定 PCS ファイバの伝送帯域は 表 4 に示した PCS ファイバの伝送帯域值 $(1 \mathrm{GHz} / 20 \mathrm{~m})$ 以上 であることが容易にわかる。

\section{2 フォトンカウンティング OTDR}

光ファイバの片端から光パルスを入射し, 光ファイバ中 で発生した後方散乱光の距離依存性を検出する OTDR (Optical-Time-Domain-Reflectmeter) は, 破断点の位置検出や光 損失測定に威力を発揮している。短尺試料を対象とする破 断点の位置検出や光損失測定では高い空間分解能が要求さ れる。その手段の 1 つがフォトンカウンティング $\mathrm{OTDR}^{7), 8)}$ である。

図 10 にフォトンカウンティング OTDR を用いた光損失測 定系を示す。光源は波長 $\lambda=650 \mathrm{~nm}$, 光パルス半值幅 $=0.2 \mathrm{~ns}$ の半導体レーザ $(\mathrm{LD})$ である。 LDからの光パルスは $2 \times 1$ カプラを介して被測定光ファイバに入射される。被測 定ファイバからの後方散乱光は $2 \times 1$ カプラを介して光電子

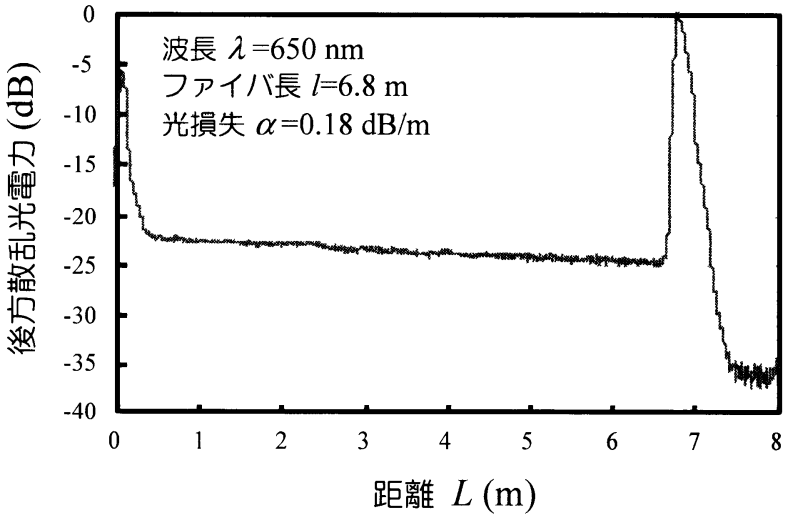

図 11.POF を収容した光ハーネスのOTDR 波形

増倍管(Photo-Multiplier)に導かれ，後方散乱波形を観測す る。図 11 は長さ $l=6.8 \mathrm{~m}$ のハーネスに収容されたPOFの $\mathrm{OTDR}$ 波形である。距離 $L=0 \mathrm{~m}$ と $6.8 \mathrm{~m}$ 近傍のピークはそ れぞれPOF入射端と遠端のフレネル反射(Fresnel Reflection) である。これらフレネル反射間の後方散乱波形の傾きから, 光損失值 $\alpha(=0.18 \mathrm{~dB} / \mathrm{m})$ が得られる。表 2,3 から，この值は MOST およびIDB-1394 の POF に対する光損失規定值を満足 していることがわかる。このように，実際に光ハーネスと して収容されたPOFに対しても，フォトンカウンティング OTDR技術は威力を発揮する。

\section{5. まとめ}

車電子化の潮流を受けて, ワイヤーハーネスは多品種化, 数量増加の傾向にあり, 省スペース化と軽量化を実現する 手段として，多重化技術を駆使できる車の光化が有効であ ることを述べた。また，情報系光 LAN として注目されてい るMOST とIDB-1394の仕様を整理し，短尺ファイバにより 光伝送特性を評価できる技術として, シャトルパルス法と 
フォトンカウンティング OTDRを紹介した。

車載実績のあるギガビットクラスの映像伝送リンクとし

て, メタル線の GVIF (Gigabit Video Interface) がすでに存在 する。しかし，今後のECUのさらなる増加と動画を中心と する映像配信デマンドによる情報量の増大が, 車の光化を 推進する大きなトリガーとなりうる。現在, 車載実績のあ る光LANはMOST@25であるが, ギガビットクラスのデー 夕速度を有する新たな規格をMOST@1000とすると，この 規格の動向も注目される。先に述べたVCSEL と PCS ファイ バの組み合わせによるFOT の構成がMOST@1000を実現す る1つの手段として有望と考える。

（2007.1.29-受理）

\section{文献}

1) 三木哲也, 青山友紀 監修: “FTTH/xDSL教科書”, アス キー出版局, 1999年

2）伊賀健一，小山二三夫 編著：“面発光レーザの基礎と応 用”，共立出版，2003年
3) L. G. Cohen: "Shuttle Pulse Measurements of Pulse Spreading in an Optical Fiber", Appl. Opt., Vol. 14, pp. 1351-1356, 1975

4) T. Tanifuji and M. Ikeda: "Pulse Circulation Measurement of Transmission Characteristics in Long Optical Fibers," Appl. Opt., Vol. 16, pp. 2175-2179, 1977

5) T. Aiba, Y. Inoue and N. Shibata: "Transmission Bandwidth Evaluation Based on Optical Pulse Circulation”, IEEE Photon. Technol. Lett., Vol. 17, pp. 1489-1491, 2005

6) K. Iwashita, K. Nakagawa, Y. Nakano and Y. Suzuki: "Chirp Pulse Transmission through a Single-Mode Fiber”, Electron. Lett., Vol. 18, pp. 873-874, 1982

7) C. G. Bethea, B. F. Levine, S. Cova and G. Ripamonti: "HighResolution and High-Sensitivity Optical-Time-Domain-ReflectMeter”, Opt. Lett., Vol. 13, pp. 233-235, 1988

8) A. L. Lacaita, P. A. Francese and S. Cova: "Single-Photon Optical-Time-Domain-Reflectometer at $1.3 \mu \mathrm{m}$ with 5 -cm Resolution and High Sensitivity”, Opt. Lett., Vol. 18, pp. 1110-1112, 1993 